\title{
DA DISTINÇÃO TEÓRICA ENTRE PRINCÍPIOS LÓGICOS, CIENTÍFICOS E JURÍDICOS
}

\author{
Josué Mastrodi Neto \\ Thiago Silva Freitas Oliveira ${ }^{2}$
}

\begin{abstract}
Resumo
Em termos realistas, entende-se o direito como consequência das relações sociais, dos valores de uma sociedade, seus interesses e vontades, e não como efeito natural ou decorrência lógica dessas mesmas relações. Nesse sentido, a ciência do direito não deve ser desenvolvida nos mesmos termos das ciências naturais ou da lógica formal. Os princípios naturais e lógicos, base das ciências naturais e da lógica, são essencialmente distintos dos princípios normativos, base da ciência do direito. A confusão entre eles acaba por apresentar o direito como se ele pudesse ser compreendido na forma de um sistema baseado em princípios naturais, para lhe dar a aparência de verdadeiro, ou baseado em princípios lógicos, para lhe dar a aparência de imutável.
\end{abstract}

Palavras-chave Direito e Ciência do Direito. Lógica jurídica. Princípios lógicos, científicos e normativos. Sistemas sociais como sistemas normativos.

\section{INTRODUÇÃO}

Este trabalho se apresenta como o primeiro produto de uma pesquisa mais ampla, sobre os problemas decorrentes da falsa identificação dos princípios jurídicos com princípios lógicos ou científicos.

Segundo uma abordagem realista, ${ }^{3}$ a criação do direito se dá a partir de relações sociais efetivas (observáveis no mundo do ser), e não a partir de pressupostos normativos (do mundo do dever ser), muito menos a partir de pressupostos lógicos. Apresenta-se o direito, neste sentido, não como algo separado do mundo do ser e prévio para a determinação deste; ao contrário, ele se apresenta como resultado de inúmeras e intrincadas relações sociais, históricas e econômicas, a partir das quais pessoas e grupos sociais consolidam suas práticas na

\footnotetext{
${ }^{1}$ Professor pesquisador da Faculdade de Direito da Pontifícia Universidade Católica de Campinas. E-mail: mastrodi@gmail.com

${ }^{2}$ Professor de Filosofia e Direito do CCHSA/PUC.E-mail: tigosofia@gmail.com

${ }^{3}$ No âmbito do programa institucional de nossa universidade, temos voltado nossas pesquisas para o aprimoramento de um conceito realista de direitos fundamentais. Em outras palavras, temos buscado indutivamente, nas relações sociais, os princípios pelos quais é possível conferir organização jurídica à sociedade. Essa pesquisa permitiu o desenvolvimento dos resultados aqui apresentados. Cf. MASTRODI, Josué. Sobre o real fundamento dos direitos fundamentais. Revista Digital de Direito Público, v. 1, 2012, p. 150-187.
} 
forma de normas sociais e, em seguida, religiosas, morais e jurídicas. ${ }^{4}$

Modernamente, a compreensão formal do objeto de estudo de uma ciência se dá por meio de sua sistematização. ${ }^{5}$ Sistema tem a ver com ordem e também com unidade. ${ }^{6}$ Sistema é forma moderna do pensamento científico que tem por premissas a identificação dos elementos que compõem o campo de estudo por meio de um critério de unidade (saber o que faz parte e o que não faz parte do sistema depende do critério adotado) e a determinação da forma pela qual os elementos se relacionam (saber qual é a ordem entre os elementos). De todo modo, sistema é um construto formal, um jogo de linguagem ${ }^{7}$ que se refere ao mundo real, mas que com ele não se confunde.

Em sistemas físicos, químicos ou biológicos, tanto a identificação do que pertence ao sistema quanto a sua organização podem ser entendidos como dados objetivos extraídos da natureza (ie, como dados pertencentes ao objeto de estudo), cabendo ao observador tão somente identificá-la e descrevê-la. Por outro lado, no mundo da cultura, e aqui nos referimos especialmente às organizações sociais, a identificação e a descrição sistemáticas não são tão objetivas quanto nas ciências naturais.

Ainda que seja possível realizar certas analogias entre sistemas lógicos, físicos e sociais, eles estão longe de possuírem identidade. Talvez a única coisa que tenham em comum seja o termo "sistema" para indicar a possibilidade de ordem e de unidade na compreensão de seus respectivos objetos.

Dessa distinção entre sistemas naturais e sistemas culturais (para esta pesquisa, reduziremos as questões de ordem social ao sistema jurídico) decorre outro problema: a construção dos sistemas das ciências naturais está relacionada a certas constantes ou probabilidades que podem ser identificadas por indução, ${ }^{8}$ o que permite o estabelecimento de leis ou princípios de caráter epistemológico. Por seu turno, o estudo das estruturas dos

\footnotetext{
${ }^{4}$ Temos consciência de que o direito, determinado pelas relações sociais, também serve para, consolidado, determiná-las, num processo dialético de implicação recíproca. Não obstante, devemos reconhecer a preexistência das pessoas e dos grupos sociais ao direito que essas mesmas pessoas e esses mesmos grupos criam. De todo modo, para fins deste trabalho, não nos ateremos à "retroalimentação" do direito. Esta pesquisa tem por foco tratar apenas da forma de compreensão e de produção do sistema normativo.

5 "Verdadeira será uma proposição cientifica racionalmente integrada a um sistema, o qual, como um todo, proporciona uma explicação satisfatória do mundo. A mudança é fundamental: trata-se de verdade dentro do sistema." CAPELLA, Juan-Ramon. El derecho como lenguaje: un análisis lógico. Barcelona: Ariel, 1968, p. 81.

6 "Há duas características que emergiram em todas as definiçōes [de sistema]: a da ordenação e a da unidade; elas estão, uma para com a outra, na mais estreita relação de intercâmbio, mas são, no fundo, de separar. No que respeita, em primeiro lugar, à ordenação, pretende-se, com ela -quando se recorra a uma formulação muito geral, para evitar qualquer restrição precipitadaexprimir um estado de coisas intrínseco racionalmente apreensivel, isto é, fundado na realidade. No que toca à unidade, verifica-se que este fator modifica o que resulta já da ordenação, por não permitir uma dispersão numa multitude de singularidades desconexas, antes devendo deixa-las reconduzir-se a uns quantos principios fundamentais." CANARIS, Claus-Wilhelm. Pensamento Sistemático e Conceito de Sistema na Ciência do Direito. Trad. A. Menezes Cordeiro. 2 ed. Lisboa: Calouste Gulbenkian, 1996, p. 12-13.

${ }^{7} \mathrm{Na}$ acepção de WiTtGenstein, Ludwig. Investigações filosóficas. Trad. José Carlos Bruni. São Paulo: Abril Cultural, 2000, em especial nas páginas 35 (\$23) e 128 (\$ 421).

${ }^{8} \mathrm{Ou}$, em termos mais téenicos, por generalização indutiva. CopI, Irving M. Introdução à lógica. Trad. Álvaro Cabral. 2 ed. São Paulo: Mestre Jou, 1978, p. 333.
} 
sistemas sociais também se utiliza dos termos leise princípios, que aqui não se referem a nada da natureza, nada do mundo do ser, mas do mundo do dever ser: as leis e princípios que regem o sistema social são em regra estabelecidos por dedução a partir de pressupostos ideais e têm caráter deontológico.

Embora haja essa distinção séria entre princípios lógicos, epistemológicos e deontológicos, é comum, nas teorias normativas, em especial nas teorias jurídicas, a utilização indistinta desses princípios como se fossem uma coisa só. Princípios de natureza prescritiva, próprios do direito, são apresentados como se fossem descritivos de uma realidade imutável, próprios da natureza, ou identificadores de uma verdade indisputável, próprios da lógica formal.

Aliás, haja vista que a lógica formal é um instrumento de verificação da correção do pensamento em relação a ele mesmo, esta funciona apenas para dar valor de verdade à estrutura conceitual, seja do sistema natural, seja do jurídico. O fato de um sistema ter sido bem estruturado não significa que ele seja verdadeiro (em termos aristotélicos, que haja adequação entre a realidade exterior objeto de sua compreensão e as descrições dadas pelo sistema), tampouco que ele seja justo (que se produza justiça no plano concreto pela simples decorrência da aplicação do sistema); apenas que é íntegro em sua lógica interna e que certos sentidos técnicos lhe são dados de antemão: no caso dos sistemas normativos, as normas recebem, pelo sistema lógico, significados precisos, como se esses significados fossem os únicos verdadeiros. Algo que, embora fictício e totalmente descolado da realidade mesma, é pressuposto como válido e estrutura a compreensão científica do direito. ${ }^{9}$

E aqui talvez resida o ponto mais sensível desta pesquisa, o problema da compreensão do direito como ele é está justamente no interesse de grupos hegemônicos, pelo qual se procura apresentar a realidade jurídica como algo tão perfeito quanto a lógica ou tão inexorável quanto o mundo físico. E tal interesse, para que seja satisfeito, impõe a ocultação das razóes pelas quais o direito é por meio de enunciados expressivos sobre como o direito deve ser. Expressões que não são passíveis de serem declaradas verdadeiras e que se sustentam não pela razão, mas pela força do que Ferdinand LASSALLE chamava de fatores reais de poder. ${ }^{10}$

\footnotetext{
${ }^{9} C f$, a este respeito, НАвА, Enrique P. Metodología realista-crítica y ética del razonamiento judicial: Realismo jurídico como alternativa práctica al discurso de los jueces. Revista Doxa - Cuadernos de Filosofia del Derecho n. 25, 2002, p. 505-506.

${ }^{10}$ LASSALLE, Ferdinand. O que é uma Constituição?'Trad. Hiltomar Martins Oliveira. Belo Horizonte: Líder, 2001, p. 42 e ss. Em termos idealistas, parece-nos que Immanuel KANT, cerca de 90 anos antes de LASSALLE, apresentou consideração análoga a deste, ao propor que nenhum pensamento poderia ficar livre da crítica da razão, pontuou que a legislação tinha interesse em se abster da crítica por causa de sua majestade: "De vez em quando, ouvem-se queixas acerca da superficialidade do modo de pensar da nossa época e sobre a decadência da ciência rigorosa. Pois eu não vejo que as ciências, cujo fundamento está bem assente, como a matemática, a fisica, etc, mereçam, no mínimo que seja, uma censura. Pelo contrário, mantêm a antiga reputação de bem fundamentadas e ultrapassam-na mesmo nos últimos tempos. Esse mesmo espírito mostrar-se-ia também eficaz nas demais espécies de conhecimentos, se houvesse o cuidado prévio de retificar os princípios dessas ciências. À falta desta retificação, a indiferença, a dúvida e, finalmente, a crítica severa são outras provas de um modo de pensar rigoroso. A nossa época é a época da crítica, à qual tudo tem que submeter-se. A religião, pela sua santidade, e a legislação, pela sua majestade, querem igualmente subtrair-se a ela. Mas então suscitam contra elas justificadas suspeitas e não podem aspirar ao sincero respeito, que a razão só concede a quem pode sustentar o seu livre e público exame." KANT, Immanuel. Crítica da Razão Pura. Trad. Manuela Pinto dos Santos e Alexandre Fradique Morujão. Baseada na edição crítica de Raymund Schmidt, confrontada com a edição da Academia de
} 
Este trabalho será desenvolvido da seguinte forma: no item 1, exporemos algumas considerações sobre lógica, sobre natureza e sobre sociedade. As considerações sobre lógica serão instrumentais -e, neste sentido, formais - para promovermos, no item 2, a compreensão da relação entre sistemas lógicos e sistemas naturais e entre sistemas lógicos e sistemas culturais (em especial o sistema normativo jurídico), principalmente quanto ao fato de que não há lógica nas relações sociais. Em outras palavras, a lógica não resolve as relações sociais porque estas não decorrem de uma causa suficiente, muito menos de um axioma lógico-dedutivo.

Embora seja possível compreender a sociedade racionalmente, isso não faz com que a sociedade opere constantemente segundo princípios lógicos bem determinados. Os princípios normativos, fundados antes em valores e em interesses que na lógica ou na verdade, são topoi, pontos de partida para argumentação. Algo a ser tratado no item 3, em que serão discutidos os dois sentidos do termo princípio no âmbito da ciência do direito, o descritivo e o prescritivo.

Não temos, neste trabalho, qualquer pretensão de discutir os modelos descritivos desenvolvidos por teóricos da lógica contemporânea. Utilizamos da lógica formal apenas como instrumento de análise e interpretação dos fenômenos naturais e sociais (em especial, os jurídicos). A lógica aqui aplicada é tão-somente um cânon (KANT, 2003) para correção do pensamento. Não temos, aqui, portanto, intenção de discutir os modelos descritivos da realidade, produzidos para compreensão dos objetos das ciências exatas e naturais, e as possíveis incongruências entre tais descrições e seus objetos. Não negamos que existam quebras de linearidade entre os modelos lógicos e a realidade mesma que se busca ser compreendia a partir de tais modelos. Não obstante, tal discussão exfoge de nosso corte epistemológico, bem como da finalidade proposta para o presente estudo, que trata, especificamente, da sistematização do direito a partir de princípios que não poderiam ser compreendidos do mesmo modo que princípios lógicos ou científicos.

\section{SOBRE LÓGICA E SISTEMAS DE PENSAMENTO}

A lógica não confere valor de verdade ao mundo. Ela é importantíssima no plano formal, já que ela compreende os métodos e princípios usados para distinguir o raciocínio correto do incorreto. Ao lógico interessa a correção do processo de raciocínio:

Sua interrogação é sempre esta: a conclusão a que se chegou deriva das premissas usadas ou pressupostas? Se as premissas fornecem bases ou boas provas para a conclusão, se a afirmação da verdade das premissas garante a afirmação de que a conclusão também é verdadeira, então o raciocínio é correto. Caso contrário, é incorreto. A distinção entre o raciocínio correto e o incorreto é o problema central que incumbe à lógica tratar. ${ }^{11}$

Usando da lógica e dos seus três princípios fundamentais como instrumentos (princípios da identidade,

Berlim e com a edição de Ernst Cassirer. 5 ed. Lisboa: Calouste Gulbenkian, 2001, p. 31.

${ }^{11}$ CopI, Irving M. Introdução à lógica, p. 21. 
não-contradição e terceiro excluído), à ciência é possível atribuir valor de verdade a todo e qualquer enunciado apofântico, isto é, a toda proposição afirmativa ou negativa:

Desde Aristóteles tem-se tradicionalmente denegado às normas, proposições estimativas etc. o estatuto de verdade ou falsidade. Já na primeira página do De Interpretatione, Aristóteles assinala que nem tudo o que se pode dizer é verdadeiro ou falso: "Assim como na mente há pensamentos que não expressam verdade ou falsidade, e outros que podem ser verdadeiros ou falsos, o mesmo ocorrem na linguagem." Segundo o filósofo, "toda oração tem sentido (não por natureza, mas sim por convenção). Mas nem toda oração é um enunciado; só os enunciados são suscetíveis de verdade ou falsidade. Assim, uma oração de súplica [aos deuses] não é um enunciado porque não é nem verdadeira nem falsa." Os enunciados nãoapofânticos - proposições não suscetíveis de verdade ou falsidade- foram excluídos de seu tratado, já que "pertencem mais ao estudo da retórica ou da poética." 12

Só as proposições podem ser afirmadas ou negadas, e nisto elas diferem das perguntas, ordens, exclamações. Só as proposições, orações declarativas, podem ter valor de verdade ou falsidade. Hans KELSEN tinha perfeito conhecimento dessas estruturas lógicas, tanto que ele nunca considerou afirmar a verdade ou a falsidade das normas, mas tão somente das proposições normativas. Normas, tanto nos estatutos da lógica quanto no âmbito da teoria pura do direito, seriam válidas ou inválidas, nunca verdadeiras ou falsas. ${ }^{13}$

Já os argumentos formados sempre por ao menos duas proposições, das quais uma é a premissa e a outra é a conclusão, estes também não podem ser considerados verdadeiros ou falsos, mas válidos ou inválidos. ${ }^{14}$ Sempre que houver adequação lógica entre premissa e conclusão, o argumento é necessariamente válido (em termos lógicos, repise-se) ${ }^{15}$ Note-se que sua estrutura formal identifica a correção do argumento em relação a ele mesmo, do texto com o texto, e nunca do texto-descrição com o objeto real descrito. A relação entre premissas e conclusões será considerada logicamente adequada -isto é, será considerada válida- se fizer sentido, ainda que esse sentido não tenha absolutamente nenhuma relação com o eventual objeto real que deu azo à redação, ou ainda que tal redação não tenha nenhuma relação com o real: os romances e as fábulas são textos que fazem pleno sentido ao seu leitor, ainda que não possuam qualquer relação com o mundo real. Para que um texto tenha sentido lógico, basta que siga os três princípios fundamentais da lógica e que os axiomas sobre os quais se fundou sejam respeitados. ${ }^{16}$

\footnotetext{
${ }^{12}$ CAPELLA, Juan-Ramon. El derecho como lenguaje, p. 90.

${ }^{13}$ Kelsen, Hans. Teoria Pura do Direito. Trad. João Baptista Machado. 6 ed. São Paulo: Martins Fontes, 2003, p. 80-84. Aliás, é justamente por isso que, em seu capítulo VIII, KELSEN nega a possibilidade de uma única interpretação correta às normas, pois também não há interpretação normativa verdadeira ou falsa. KELSEN, op. cit., p 393-396.

14 "Verdade e falsidade podem ser predicados das proposiçóes, nunca dos argumentos. Do mesmo modo, propriedades de validade ou invalidade só podem pertencer a argumentos dedutivos, mas nunca a proposiçôes." CopI, Irving M. Introdução à lógica, p. 38.

15 "...como a validade é uma noção formal, um argumento é válido se somente a forma de raciocínio for uma forma de raciocínio válida." CopI, Irving M. Introdução à lógica, p. 243.

${ }^{16}$ Um exemplo sobre premissas falsas e argumento verdadeiro pode ser obtido na obra de Irving Copi:" Alguns argumentos válidos contêm apenas proposiçôes verdadeiras, como, por exemplo:Todas as baleias são mamíferos. Todos os mamíferos têm pulmões. Portanto, todas as baleias têm pulmões. Mas um argumento pode conter exclusivamente proposições falsas e, apesar disso, ser válido, como, por exemplo: Todas as aranhas têm seis pernas. Todos os seres de seis pernas têm asas. Portanto, todas as aranhas têm asas.
} 


\section{Os três princípios fundamentais da lógica}

Segundo a lógica formal, tudo seria uno, idêntico a si mesmo, sem qualquer possibilidade de transformação. Tempo e espaço seriam conceitos falsos, ${ }^{17}$ que apenas confundiriam nosso intelecto por meio dos sentidos. Os objetos só podem ser reconhecidos e apreendidos pelo pensamento por meio de conceitos que os representem idealmente de modo formal, atemporal e a-histórico.

Por conta do axioma parmenídico, segundo o qual tudo é um e que esse um é igual a si mesmo, foram desenvolvidos os três princípios fundamentais da lógica formal, quais sejam, o princípio da identidade, o da nãocontradição e do terceiro excluído, que são a base formal e condição de possibilidade do pensamento, a partir dos quais é possível atribuir sentido ao raciocínio para, em seguida, atribuir-lhe valor de verdade ou de falsidade. Compreender isso é estabelecer as condições gerais para se expressar o mundo sob a estrutura de uma predicação lógica e ontologicamente realizável. "Segundo o pensamento clássico-afirma Alaôr Caffé ALVES - tais princípios são comuns a toda e qualquer ciência, no sentido de que o saber científico não pode contrariá-los, sob pena de incoerência e falsidade". ${ }^{18}$

Também conhecidos como as "três leis do pensamento", os três princípios fundamentais da lógica formam as condições necessárias e suficientes para que o pensar se desenvolva de maneira "correta". A lógica

Este argumento é válido porque, se suas premissas fossem verdadeiras, sua conclusão também teria que ser verdadeira, mesmo no caso em que, de fato, fossem todas falsas." CopI, Irving M. Introdução à lógica, p. 38.

${ }^{17}$ PARMÊNIDES DE ELEIA (530?-460?a.C.), primeiro filósofo do pensamento ocidental a apresentar a noção de ser (ontos) e a possibilidade de conhecer o ser das coisas por meio de um método, de cujos princípios se desenvolveram os estudos sobre a lógica formal. O ser e o pensar coincidem para esse pensador, de modo que tudo o que é pensado pode existir, e o que não pode ser pensado não pode existir, por ser absurdo: dos sentidos viria apenas engano e aparência, pois a identidade real existe apenas entre ser e pensamento (NIETZSCHE, Friedrich. A Filosofia na Época Trágica dos Gregos (\$S 9, 10, 11, 12 e 13). In Os Pré-Socráticos: Vida e Obra. Coleção os Pensadores. Trad. José Cavalcanti de Souza et al. São Paulo: Nova Cultural, 1996, p. 136-137). Baseando seu pensamento na compreensão de que tudo faz parte de um único ser (o seré sinônimo de um e é sempre igual a si mesmo), nega a possibilidade de tempo e de movimento (PARMÊNides De Eleia. Fragmentos. In Os Pré-Socráticos: Vida e Obra. Coleção os Pensadores. Trad. José Cavalcanti de Souza et al. São Paulo: Nova Cultural, 1996, p. 119). Apresenta-se uma aporia: como podem as coisas da natureza se transformar umas nas outras, serem criadas, se desenvolverem e terem fim, se o ser parmenídico é imóvel, não muda, não se transforma? A consideração de que não pode haver movimento (pois este é ilógico e, portanto, absurdo) impõe entender que a mente é iludida pelos sentidos (NiETzSCHE, Friedrich. A Filosofia na Época Trágica dos Gregos, p. 136137). Para manter a consistência de seu pensamento, PARMÊNIDES nega a mobilidade da physis por afirmar a imutabilidade do ser. ${ }^{18}$ Trata-se, segundo este autor, de "juízos de evidência imediata e regulam nossos conhecimentos em suas relaçóes recíprocas. Deles não se tira conhecimento material algum, mas por eles organizamos o pensamento de maneira necessária para conclusões apodíticas. Esses princípios regulam as nossas inferências de modo preciso e exato. Assim, eles são necessários, universais e evidentes. Do ponto de vista da Lógica clássica, são necessários porque não dependem de nenhuma condição, ou seja, porque sua verdade não pode ser de outra maneira, pois valem sempre, sem exceção. São universais porque valem para todas as inteligências e todos os homens os entendem e os aplicam ao pensar, visto que são válidos para todo entendimento humano. Exemplo paradigmático dessa universalidade é o pensamento matemático, válido para todos os homens. E são evidentes porque se apresentam com tal clareza ao nosso entendimento que não necessitam de demonstração. Na verdade, como princípios de origem primária e radical não podem ser demonstrados. Eles se impõem imediatamente ao nosso espírito mediante uma intuição intelectual. Para usar quase uma analogia, é como se víssemos diretamente, com os olhos do corpo, uma determinada cor. Quando vejo o vermelho, vejo-o diretamente, não precisando de nada intermediário para sentir essa cor. Por isso, eles, os princípios, são as 
formal está integralmente submetida a essas três leis:

Essas leis do pensamento receberam, tradicionalmente, os nomes de Princípio de Identidade, Princípio de Contradição (por vezes, Princípio de Não-Contradição) e Princípio do Terceiro Excluído. Há formulações alternativas desses princípios, apropriadas a diferentes contextos. No nosso caso, as formulações apropriadas são as seguintes: $\mathrm{O}$ princípio de Identidade afirma que se qualquer enunciado é verdadeiro, então ele é verdadeiro. $\mathrm{O}$ princípio de contradição afirma que nenhum enunciado pode ser verdadeiro e falso. $\mathrm{O}$ princípio do Terceiro Excluído afirma que um enunciado ou é verdadeiro ou éfalso. ${ }^{19}$

Não obstante, algo que precisa ficar claro é que, como a lógica serve à correção do pensamento, precisa haver pensamento para que, então, haja a ciência da lógica. Mais que isso, é preciso haver alguém pensante para pensar, e pensar logicamente. A lógica não é autônoma em relação ao pensamento, tampouco em relação ao serque-pensa. Mais ainda, e sobre isto pretendemos discorrer mais adiante, é que é esse ser, cuja consciência é formada no âmbito de relações sociais, quem determina as condições de seu pensamento.

\section{Os axiomas do sistema lógico}

Axioma é termo que significa o ponto de partida inegável do sistema, sua premissa fundamental. Trata-se da premissa que deverá ser levada em conta em toda e qualquer operação lógica no âmbito desse sistema. Trata-se de formalizações sintáticas, com conteúdo proposicional assumido como verdadeiro, e sobre tal enunciado todo o sistema é construído. Toda nova premissa apresentada, cujo conteúdo seja contraditório em relação ao conteúdo dos axiomas, será excluída do sistema. Por outro lado, toda e qualquer conclusão que se extraia desses axiomas é considerada verdadeira em relação a eles e, desse modo, integra o sistema.

À guisa de exemplo no campo da física, tome-se por axioma que a luz possuiria natureza ondulatória. $\mathrm{Na}$ construção de um sistema de descrição dessa realidade, nega-se a possibilidade de a luz possuir natureza de partícula, premissa fundamental de outra teoria sobre o mesmo objeto (em que pesem as duas teorias, a luz continuou a existir independentemente de se saber se ela era apenas onda, apenas partícula ou se possuiria as duas características, como se afirmou em teoria posterior). Já no campo do direito, tome-se, por exemplo, um sistema em que se deva respeitar a vida em qualquer circunstância: nele, faz sentido autorizar o aborto em caso de risco de morte da mãe (para salvar sua vida), mas não faz sentido, por contraditório em relação à premissa fundamental desse sistema, aceitar o aborto em caso de estupro. Aliás, este exemplo demonstra muito bem que o sistema jurídico não é lógico nem natural, pois, se o fosse, o artigo 128, II, do Código Penal, que autoriza o aborto em caso de estupro, teria sido excluído do sistema normativo, já que em confronto absoluto com a garantia constitucional do direito à vida.

condiçōes a priori de todo e qualquer conhecimento demonstrado. São as leis fundamentais e primeiras do pensamento, e sua verdade é captada diretamente, sem rodeios" ALVES, Alaôr Caffé. Lógica, p. 338-339.

${ }^{19}$ CopI, Irving M. Introdução à lógica, p. 256. 


\section{SISTEMAS DE PENSAMENTO: SISTEMAS LÓGICOS, CIENTÍFICOS E NORMATIVOS}

O sistema é uma construção lógica que se refere exclusivamente a si próprio. Todas as suas operações têm natureza dedutiva e decorrem de seus axiomas. Daí porque, no conceito de sistema, não se admitem lacunas ou contradições. O sistema, ao se reafirmar em cada operação interna, tanto se completa quanto se confirma. Pelo sistema, pode-se tanto descrever a realidade externa - e talvez a finalidade originalmente concebida para o sistema tenha sido justamente essa - quanto construir um arcabouço normativo pelo qual a realidade social é prescrita em vez de descrita.

Conforme se depreende do afirmado até aqui, os sistemas podem ser construídos sobre quaisquer fundamentos, sejam estes reais, sejam estes ideais. O sistema, para ser sistema, basta que possua critérios de ordenação e de unidade e que funcione pela reprodução dedutiva de seus axiomas. Tais premissas fundamentais podem ser de uma das seguintes três naturezas:

a. um antecedente pelo qual as operações sistêmicas produzirão consequentes, isto é, um axioma exclusivamente formal, sem relação necessária com a realidade material, como um programa de computador;

b. uma causa-real ou fictícia - a partir da qual os objetos da realidade, empiricamente identificados, são explicados como efeitos dessa causa, segundo o princípio da causalidade, a exemplo de como compreendemos o mundo natural, $\mathrm{e}$

c. uma causa - real ou fictícia - a partir da qual são estabelecidas consequências segundo o princípio da imputação, que não serve para descrever a realidade, mas tão-somente para determinar a imposição de certas condutas, nos termos de como compreendemos o âmbito do direito.

Neste sentido, visando a distinguir os sistemas de pensamento conforme a premissa fundamental ou axioma sobre o qual eles são construídos, consideramos que os sistemas podem ser compreendidos como lógicos, naturais ou culturais. ${ }^{20}$

\section{Sistemas lógicos}

Em estudos ligados à lógica formal e às ciências exatas, os axiomas são úteis para descrição de

\footnotetext{
${ }^{20}$ Aqui não se pode deixar de mencionar Humberto ÁvilA e sua definição aclaradora do termo princípio como axioma, como postulado e como norma jurídica. Cf. ÁvILA, Humberto. Repensando o princípio da supremacia do interesse público sobre o particular. Revista Diálogo Jurídico. Ano I. vol. I. n. 7, out/2001, p. 3 e ss. No entanto, nossas considerações a respeito do que o autor entende por postulado e suas aplicações na ciência do direito divergem de suas afirmações em aspectos metodológicos, de modo que não é possível esquematizar diretamente as distinções dele, princípio-axioma, princípio-postulado e princípio-norma com os sistemas lógico, natural e cultural.
} 
características que decorrem da premissa fundamental como se aquelas qualidades só existissem porque são consequentes lógicos da ficção. São corolários, passíveis de análise apriorística independentemente da experiência. Nos termos de Alaôr Caffé ALVES, esse axioma é a condição de toda a afirmação e de todo o conhecimento. ${ }^{21}$ Para Claus-Wilhelm CANARIS, axioma é termo pelo qual se denota uma veracidade aceita de forma apriorística, de cujo conteúdo seria possível deduzir conclusões por dedução puramente lógico-formal. ${ }^{22} \mathrm{O}$ axioma se apresenta em anterioridade lógica, e não cronológica (fora do tempo), a partir da qual deduzimos todas as propriedades do objeto de estudo. Todos os consequentes são deduções lógicas dos antecedentes, de modo que o sistema é logicamente perfeito, isento de erros ou contradições internas.

Por exemplo, a afirmação de que o miriágono é um polígono formado por dez mil lados, como se fosse possível existir um corpo sólido assim, mas que temos a certeza dos dez mil lados que o compõem simplesmente pela análise do objeto fictício que se apresenta como se existisse; ou que a geometria e a matemática possuem objetos de estudo como se estes existissem na realidade, como se o ponto geométrico não tivesse extensão ou a reta não tivesse largura; como se fosse possível haver um número extraído da raiz quadrada de um negativo(ou raiz quadrada de menos um: $\sqrt{-}-1)$-o chamado número imaginário $(i)$-que, embora não exista na realidade, ${ }^{23}$ é passível de demonstração matemática (logo, ele é válido) e de fundamental utilidade prática para uma série de aplicações em várias áreas da engenharia. Ou, ainda, que o sistema social luhmanniano é autorreferente, circular e recursivo, como se o sistema social fosse não só lógico como autopoiético, pois todas aquelas qualidades decorrem lógica e transcendentalmente (isto é, fora da experiência possível) do objeto. ${ }^{24}$

Por se tratar de uma estrutura que opera exclusivamente a partir da lógica dedutiva, toda definição apresentada no âmbito do sistema é concludente, isto é, um resultado necessário, pois a operação lógica impõe ao pensamento um único resultado possivel e verdadeiro (outros resultados são impossíveis ou falsos). Considerando-se que o axioma é verdadeiro, todas as conclusões produzidas pelas operações do sistema também são, necessariamente, tão verdadeiras quanto o axioma.

\footnotetext{
${ }^{21}$ Alves, Alaôr Caffé. Lógica, p. 159.

${ }^{22}$ CANARIS, Claus-Wilhelm. Pensamento sistemático e conceito de sistema na ciência do direito, p. 38.

23 "A matemática, como um todo, constitui o exemplo clássico de um engenhoso instrumento de expediente mental para facilitar a operação do pensamento" (VAIHINGER, Hans. The philosophy of 'as if.Trad. para o inglês de C. K. Ogden. Londres: Routledge, 1952, p.57). Ressalte-se, não obstante, o fato de matemáticos afirmarem a existência real do número imaginário: "Conheço quatro conjuntos distintos onde, em cada um, a palavra número tem um significado diferente. Em nenhum deles existe a raiz quadrada de 1. Será que existe um quinto conjunto, onde número tenha um significado completamente diferente daquele que conheço e onde exista a raiz de -1? A resposta a esta questão é Sim, existe. Chama-se Conjunto dos Números Complexos e envolve uma noção diferente de número daquela que conhecemos. No entanto, essa diferença não é maior do que a existente entre números inteiros e fracçôes." ALVES, Paula e VAZ, Catarina. O número imaginário existe realmente? Disponível em http://www.educ.fc.ul.pt/docentes/opombo/seminario/euler/iexistehtm. Tal realidade, porém, é abstrata e não concreta, pois decorrente de uma ficção.

${ }^{24}$ O problema em relação a este último exemplo, o conceito de autopoiese social, reside no fato de que ele é apresentado num campo de aplicação próprio da lógica formal, quando na verdade ele se refere apenas a sistemas prescritivos. A este respeito, $c f$. AUTOR.Título. Revista, n, ano, 2011, p.161-167.
} 
O sistema lógico não precisa ter qualquer relação de pertinência ou adequação com a realidade externa a ele (o chamado meio ambiente). Ele pode, pura e simplesmente, realizar suas operações internas independentemente dos fatos que ocorrem em seu exterior, já que:

As leis lógicas não se submetem à contingência da observação ou da experiência sensorial, pois elas possuem uma evidência tal que as faz não necessitar de serem controladas mediante comparações com os processos reais do mundo. Estas leis (lógica) não se referem a realidades concretas existentes no tempo e no espaço. São leis ideais de evidência imediata. ${ }^{25}$

\section{Sistemas científicos ou naturais}

Nas ciências naturais, busca-se a explicação das coisas pela compreensão das causas que determinam sua ocorrência. Tudo é entendido a partir do princípio da causalidade, ${ }^{26}$ pelo qual as coisas se relacionam por meio de causa e efeito. Tudo que existe no mundo real é efeito de causas cronologicamente anteriores. ${ }^{27}$

Toda coisa existente poderia não existir, sendo, portanto, contingente, porque tem a sua razão de ser fora de si mesma. Se uma coisa existisse absolutamente (necessariamente), isto é, por si mesma, sua explicação seria encontrada em si mesma. Ora, todas as coisas no mundo não se explicam por si mesmas e sim por outras que são sua razão suficiente (causa) de ser. Com estas outras por sua vez repete-se o mesmo processo, indo indefinidamente até a causa primeira que, segundo a ontologia clássica, tem em si a razão de ser: Deus.

Este princípio, quando aplicado aos dados da experiência (segundo KANT), é importantíssimo para a investigação científica, pois o cientista, diante de um fenômeno desconhecido, move-se a explicá-lo em virtude de saber, aprioristicamente, que dito fenômeno deve necessariamente ter uma causa que determinou seu aparecimento, embora possa não conhecê-la ainda. Ele se lança à pesquisa para saber sobre a causa do fenômeno, precisamente porque sabe, de antemão, que há uma causa determinante, ainda que não a conheça especificamente. ${ }^{28}$

A relação de causa e efeito indica a circunstância em que um fato decorre da ocorrência de outro fato, anterior a ele. A identificação da causa eficiente em cada situação específica não se dá por pensamento dedutivo, do universal para particular, mas indutivo, de um particular para outro particular. Se no pensamento dedutivo a própria operação lógica confere valor de verdade à conclusão, pois esta decorre da verdade da premissa ou do axioma, no pensamento indutivo isso não acontece. ${ }^{29} A$ verdade da causa precisa ser testada, descoberta empiricamente pelo recurso à experiência. ${ }^{30}$ Ainda que se possa observar um fato e também sua causa, é preciso

\footnotetext{
${ }^{25}$ Alves, Alaôr Caffé. Lógica, p. 135.

${ }^{26}$ Este princípio tem natureza ontológica e não lógica, e pode ser compreendido, no âmbito das definições de Humberto ÁvILA, como um postulado. Cf.ÁviLA, Humberto. Repensando o princípio da supremacia do interesse público sobre o particular, p. 5-6.

${ }^{27}$ Não cabe, aqui, discutir sobre a distinção entre causas necessárias e suficientes; não obstante, algo só pode ser efeito de uma causa que seja não só necessária, mas suficiente para a realização desse efeito (assim, pode haver um conjunto de fatos como necessários para que algo ocorra e, no conjunto, tornam-se causa suficiente). Nesse sentido, utilizemos a expressão causa eficiente para identificar o fundamento do princípio da causalidade.

${ }^{28}$ ALVES, Alaôr Caffé. Lógica, p. 156.

${ }^{29}$ Cf., sobre o método de dedução e a prova formal de validade, CopI, Irving M., Introdução à lógica, p. 259-280 e, sobre o método de indução, p. 329-376.

30 "Ousarei afirmar, como proposição geral, que não admite exceção, que o conhecimento desta relação [de causa e efeito] não se obtém, em nenhum caso, por raciocínios a priori, porém nasce inteiramente da experiência quando vemos que quaisquer objetos
} 
buscar a constatação da relação de causa e efeito entre eles; em outras palavras, é necessário identificar se essa causa sempre determina o mesmo efeito.

Grosso modo, uma ciência como a física funciona aproximadamente assim: se há alguns fatos $\mathrm{A}_{1}, \mathrm{~B}_{1}$, que podem ser explicados mediante uma hipótese $\mathrm{H}_{1}$; segundo $\mathrm{H}_{1}$ deve ocorrer na natureza um fato $C_{1}$, que até o momento se desconhece; se examina empírica ou experimentalmente se $\mathrm{C}_{1}$ ocorre na natureza, e em caso afirmativo $\mathrm{H}_{1}$ é confirmada (do contrário, é refutada); por procedimentos análogos se estabelecem outras hipóteses, $\mathrm{H}_{2}, \mathrm{H}_{3}$, $\mathrm{H}_{4 . . .}$ Um novo passo consiste em estabelecer uma teoria, isto é, de uma nova hipótese T que implique as hipóteses $\mathrm{H}_{1} \ldots \mathrm{H}_{4}$, assim como uma nova hipótese $\mathrm{H}_{\mathrm{n}}$ que, por sua vez, ao ser confirmada pelos fatos $A_{n}, B_{n}, C_{n}$, que não foram utilizados para estabelecê-la, confirma a teoria. ...Como se pode ver, são os fatos $A_{n}, B_{n}, C_{n} \ldots$ que confirmam o enunciado teórico $T .31$

Nesse sentido, ao contrário dos sistemas lógicos, em que suas operações se dão por dedução e, por isso, é possível deduzir o consequente do antecedente, toda verificação dos fatos na natureza somente pode se dar por observação e comprovação empírica. Caso não se saiba a causa de um fenômeno, ou caso se considere saber qual é de fato sua causa, é preciso testar as hipóteses pelas quais a causa seja identificada. São os testes que confirmam ou refutam o estabelecimento de uma lei causal, pela qual é possível identificar e explicar a causa dos fenômenos físicos, biológicos, químicos etc. e, pela lei causal, determinar a regularidade e precisão desses mesmos fenômenos.

Como se trata de identificar uma causa verdadeira, os testes confirmatórios sustentam a validade da teoria. Isto é, como a causa foi definida a partir de inúmeros fenômenos, deduz-se que essa mesma causa determinará a ocorrência de um novo fenômeno nos mesmos termos previstos naquela teoria. Porém, se num teste em que a suposta causa é produzida, o novo fenômeno não ocorrer em seguida da ocorrência daquela causa, a busca da verdade impõe que se restabeleçam os estatutos da teoria. Numa colisão entre a teoria explicativa da realidade e a realidade mesma, esta é que impõe mudança na teoria, não o contrário. Nesse sentido, toda ciência e todo discurso lógico opera a partir de um sistema que permite quebras de paradigmas. Nesse cenário, a noção de verdade é um instrumento da linguagem para verificar certas propriedades objetivas das coisas.

A causa de um fenômeno não precisa ser outro fenômeno, passível de ser identificado pelos nossos sentidos, a exemplo da gravidade, pela qual a lei da gravitação universal explica a causa da atração dos corpos. Muitas vezes, se não todas as vezes, a causa não é facilmente detectável. A busca pela causa real imprescinde da elaboração de hipóteses, a partir das quais o cientista pode trabalhar a solução do problema, por meio de testes visando a confirmação ou refutação da hipótese pesquisada.

A hipótese não passa de uma ficção, algo que não existe na realidade, não obstante, trata-se de algo útil:

particulares estão constantemente conjuntados entre si. Apresente-se um objeto a um homem dotado, por natureza, de razão e habilidades tão fortes quanto possível; se o objeto lhe é completamente novo, não será capaz, pelo exame mais minucioso de suas qualidades sensíveis, de descobrir nenhuma de suas causas ou de seus efeitos. ... Nenhum objeto jamais revela, pelas qualidades que aparecem aos sentidos, tanto as causas que o produziram como os efeitos que surgirão dele; nem pode nossa razão, sem o auxílio da experiência, jamais tirar uma inferência acerca da existência real e de um fato. "HuME, David. Investigação acerca do entendimento humano. Trad. Anoar Aiex. São Paulo: Nova Cultural, Coleção Os Pensadores, 1996, p. 49-50.

${ }^{31}$ CAPELlA, Juan-Ramon. El derecho como lenguaje, p. 84. 
vale-se de ficções a partir das quais se modela uma teoria descritiva da realidade, de modo que os fatos naturais serão descritos como se fossem efeitos diretos da causa fictícia. A ficção é apresentada como a causa eficiente ${ }^{32}$ dos fenômenos naturais a serem estudados por meio da teoria, a partir da qual é possível entender os fenômenos segundo uma determinada ordem ou estrutura. Por exemplos, em astrofísica, a descrição da entropia dos corpos celestes é comumente afirmada como efeito do fictício big bang; ou a ficção de que a luz viaja a 300 mil quilômetros por segundo, que permite a aplicação de relações de causa e efeito entre espaço e matéria dentro da teoria da relatividade. Ou, ainda, a existência de partículas atômicas e subatômicas como elementos constitutivos de toda a realidade física.

Ainda que a causa real seja substituída pela causa fictícia (a hipótese), ela é definida como o axioma do sistema científico, construído para o fim de identificar os fenômenos da realidade integrantes desse mesmo sistema: pertence ao sistema tudo o que puder ser compreendido como efeito da causa posta ou pressuposta.

O sistema científico, ainda que descritivo da realidade, possui certa autonomia em relação a esta, mas uma autonomia no âmbito dos critérios e princípios utilizados nas descrições. A relação de causa e efeito, considerada ontologicamente como própria da realidade natural, é transcrita no interior do sistema como uma relação lógica de antecedente e consequente. Isso significa dizer que o sistema funciona mesmo se a causa definida como axioma não for adequada à realidade: as operações internas do sistema produzirão conclusões lógicas que decorrem da verdade do axioma, como se esses consequentes fossem efeitos reais da causa. Eis porque as teorias científicas, sejam as que ainda não foram comprovadas pela observação empírica, sejam as que já tenham sido refutadas pelo mesmo motivo, funcionam perfeitamente na forma de sistema. ${ }^{33}$

Falamos há pouco que, numa colisão entre a teoria explicativa da realidade e a realidade mesma, é a primeira quem deve ser modificada para buscar adequação à verdade de seu objeto de estudo. A este propósito,

\footnotetext{
${ }^{32}$ Ressalte-se, não obstante, que a própria relação de causa e efeito é um conceito fictício para Hans VAIHINGER: "Apenas dentro do pensamento discursivo é que essas categorias possuem algum sentido e alguma justificação, porque aí elas servem para permitir operações lógicas. Apenas no mundo de nossas ideias pode haver coisas que são causas; no mundo real essas ideias são apenas ecos vazios. A ideia de causalidade é inteiramente inaplicável à realidade mesma. A realidade verdadeira não tolera essa categoria. Se sensações são, de fato, realidade essencial, então sua redução, junto com o espaço, matéria etc., ao impacto de algum objeto desconhecido, é uma extensão injustificada do conceito de causa e efeito... Quando, portanto, Kant reduz sensaçóes, junto com espaço, tempo etc. ao sistema de coordenadas de causa e efeito, objeto e sujeito, o mundo inteiro vem a ser apresentado e entendido como se fosse um efeito." VAIHINGER, Hans. The philosophy of 'as if, p. 75. Ainda assim, consideramos adequado distinguir os sistemas de pensamento lógicos dos sistemas naturais -e, pelo mesmo motivo, o pensamento da realidade material-a partir da distinção entre as relações de antecedente e consequente e de causa e efeito.

${ }_{33}$ Por exemplo, tomemos qualquer das várias teorias criadas, ao longo da história, para explicar fenômenos naturais, e que acabaram sendo refutadas em um momento ou outro por conta da descoberta das reais causas dos fenômenos. Ela possui premissas fundamentais e, a partir destas, realiza suas operações independentemente de terem sido comprovadas falsas, isto é, não condizentes com a realidade. Assim são a teoria geocêntrica da astronomia ou a teoria dos humores de Galeno. Todas essas teorias são construídas na forma de sistemas lógicos que funcionam a partir de suas premissas fundamentais, que em momento algum são negadas ou contrariadas. Quando da comprovação de que a teoria heliocêntrica e a medicina moderna descreveriam as realidades de seus objetos de estudo de modo a refutar as descrições das teorias anteriores, estas foram deixadas de lado. No entanto, ambas as teorias refutadas eram logicamente coerentes e muito bem estruturadas a partir de suas premissas.
} 
uma coisa deve ficar bem clara: a causa eficiente jamais é decidida pelo cientista, mas descoberta. As coisas não acontecem na natureza por decisão dos homens, mas por efeito de suas causas. Daí porque as leis causais são constantes: ${ }^{34}$ embora não tenham sido desenvolvidas exclusivamente por lógica dedutiva, elas descrevem situações que, nas mesmas condições, tendem a ocorrer inexoravelmente sempre e de mesmo modo.

\section{Sistemas culturais ou normativos}

As ciências sociais foram desenvolvidas inicialmente segundo o paradigma das ciências naturais. Buscase, ao menos no início, por força do positivismo filosófico do final do século XIX, a criação de uma física social. ${ }^{55}$ Até no campo do direito, da jurisprudência dos conceitos à teoria pura de Hans KELSEN, defendia-se o estatuto científico. Os cientistas sociais sempre buscaram identificar regularidades na teia social e explicar a sociedade a partir de certas hipóteses de pesquisa: grosso modo, para Karl MARX, a sociedade é explicada a partir da luta de classes; para Émile DURKHEIM, pelo fato social; para Max WEBER, pela ação social; para Jürgen HABERMAS, pela ação comunicativa. O cientista do direito KELSEN buscava tão-somente descrever seu objeto de estudo, o direito, por meio de proposições que definissem o que o direito, posto pelas autoridades, era.

No entanto, há uma diferença fundamental entre os estudos da natureza e os estudos da sociedade: naqueles, são as características do próprio objeto de estudo que determinam sua compreensão objetiva. Nas ciências naturais, busca-se tão-somente a descrição explicativa dos fenômenos: essas descrições são juízos de fato, proposições verdadeiras ou falsas (se verdadeiras, confirmadas; se falsas, refutadas). Já nas ciências da cultura, que aqui trataremos como sociais, a descrição do objeto de estudo está irremediavelmente "contaminada" pela visão de mundo do observador que, embora descreva a realidade social, tal descrição (tal juízo de fato) está fundada em juízos de valor, em especial porque o observador é parte integrante de seu objeto de estudo. O cientista natural não escolhe os resultados de sua pesquisa: ainda que ele decidisse manter uma teoria que fosse contrária a novos testes, a comunidade científica refutaria os resultados falseados por ele. Já nos estudos sobre cultura e sociedade, os valores e interesses sociais envolvidos modificam irremediavelmente a busca pelo conhecimento do objeto de estudo, especialmente porque os valores e interesses sociais, que são a principal característica do mundo da cultura, não são apreensíveis com a objetividade pela qual se apreendem os fatos da natureza. No máximo, poderíamos falar de graus de objetividade, partindo de um ponto mínimo de interferência dos valores ao ponto

\footnotetext{
${ }^{34}$ Algo que, desde KELSEN, é de pacífico entendimento no âmbito da ciência do direito: "O passo decisivo nesta transição de uma interpretação normativa para uma interpretação causal da natureza, do princípio da imputação para o princípio da causalidade, reside no fato de o homem se tornar consciente de que as relações entre as coisas -diferentemente da relação entre os homens-são determinadas independentemente de uma vontade humana ou supra-humana ou, o que vem a dar no mesmo, não são determinadas por normas, de que o comportamento das coisas não é prescrito ou permitido por qualquer autoridade." KELSEN, Hans. Teoria pura do direito, p. 95.
} 
máximo.

Ao fim e ao cabo, não é o objeto de estudo que se impõe impessoalmente como premissa fundamental do sistema normativo: os valores e interesses que interessam ao cientista social são escolhidos como o axioma do sistema e passam a organizar toda a compreensão do conhecimento naquela área. Tais valores e interesses envolvem muito mais questões de persuasão moral, psicológica e retórica do que lógicas, e são apresentados como lugares-comuns (topoi), acordos semânticos mais ou menos amplos a partir dos quais se organizam as discussões no campo social. Não são passíveis de demonstração, pois não são lógicos, tampouco de explicação causal, pois não se referem à natureza. Os topoi são, portanto, invenções úteis para organização social segundo certos valores e interesses apresentados como os mais adequados.

Se o homem produz cultura justamente ao transformar a natureza, a finalidade da transformação é o que determina o sentido da própria cultura. ${ }^{36} \mathrm{O}$ mundo cultural somente pode ser compreendido a partir da finalidade que é dada a ele pelo homem. Se os axiomas do sistema natural são obtidos a partir da observação objetiva da natureza, no âmbito cultural não é bem assim. O axioma do sistema normativo é estabelecido a partir do modo como cada homem ou grupo social compreende a cultura e a sociedade, conforme o sentido que ele dá ao mundo cultural, de acordo com seus valores e interesses.

Dessa forma, pela imposição de critérios valorativos que passam a exercer a função de axioma, o sistema cultural não realizará operações de descrição da cultura ou da sociedade, definindo como elas são, mas como a cultura ou a sociedade devem ser compreendidas. O sistema normativo, antes de descrever o mundo da cultura, o prescreve. Niklas LUHMANN desenvolveu intensamente uma teoria sobre sistemas sociais, tendo afirmado a função descritiva destes em equiparação à dos sistemas naturais. ${ }^{37}$ Em trabalho anterior, alertamos para o caráter deontológico dos sistemas sociais luhmannianos, haja vista que esse autor não reconhecia que o axioma sistêmico tinha natureza prescritiva. ${ }^{38}$ Essa consideração sobre os sistemas da teoria de LUHMANN serve para a

\footnotetext{
${ }^{35}$ Sobre Auguste Comte e sua filosofia positiva, cf. CASSIRER, Ernst. Antropologia Filosófica: Ensaio sobre o homem. Trad. Vicente Felix de Queiroz. 2 ed. São Paulo: Mestre Jou, 1977, p. 110-112.

36 "A característica notável do homem, a marca que o distingue, não é sua natureza metafísica ou fisica -mas seu trabalho. É este trabalho, o sistema das atividades humanas, que define e determina o círculo de humanidade." CASSIRER, Ernst. Antropologia Filosófica: Ensaio sobre o homem, p. 116. A este respeito, cf. ainda p. 347-357.

${ }^{37}$ Cf. Luhmann, Niklas. Social Systems. Trad. para o inglês de John Bednarz. Stanford: Stanford University Press, 1995, p. 408, em que o sistema social ideal é equiparado à sociedade real (se bem que, para esse autor, apenas as comunicações compõem a sociedade, deixando as pessoas, as comunicadoras, de fora): "A sociedade é o sistema social autopoiético par excellence."

${ }^{38}$ Naquela oportunidade, afirmamos: "A função de pôr ordem tem uma claríssima qualidade de aplicação de um senso de dever, de determinação de condutas segundo o critério de organização. O que é entendido como conforme o critério está em ordem e recebe uma identificação positiva, o que é entendido como não-conforme, uma identificação negativa. Mais do que simplesmente descrever algo, mais do que apenas classificar os objetos segundo seu código interno, o sistema social autopoiético comunica que esse algo deve ser entendido como algo positivo ou negativo, como algo que deve ser conduzido segundo a ordem do sistema. Ainda que a teoria da autopoiese social não descreva condutas ou ações sociais, mas tão-somente comunicações, é inegável que tais comunicações têm por consequência a cristalização de expectativas normativas e a pacificação social, havidas como se o sistema autopoiético tivesse determinado tais condutas. O modelo ideal do sistema social autopoiético descreve a si próprio, isto é, trata-se
} 
compreensão de qualquer sistema normativo: valores e interesses são transcritos na forma de axiomas e dados como verdadeiros. Tais axiomas servem de parâmetro para definir se as condutas humanas são adequadas ou inadequadas e não para descrever essas mesmas condutas.

KELSEN, quando distinguiu ciência causal da ciência normativa (aqui incluídas as ciências que estudam o direito e a ética), atribuiu àquelas a busca pelo conhecimento de processos reais, e a estas a busca pelo "conhecimento e descrição de normas jurídicas e às relações, por estas constituídas, entre fatos que as mesmas normas determinam" ${ }^{39}$ Ao separar de modo absoluto o mundo do ser do mundo do dever ser, KELSEN afirma possível que a ciência do direito descreva o direito de modo neutro, imparcial etc. No entanto, o estabelecimento do direito como ordem coativa (a determinação de conteúdos normativos a serem seguidos pelos membros da sociedade) teve por base certa visão de mundo que, na conjunção das forças sociais, cristalizou as condutas que se considerava devidas na forma de norma jurídica. Esses conteúdos normativos não caíram do céu, as normas jurídicas simplesmente foram abstraídas de situações encontráveis da prática social.

Do mesmo modo que ocorre na relação entre natureza e sistemas científicos, os sistemas normativos também possuem autonomia em relação à realidade social. Neste caso, estabelecem-se valores e interesses como os pressupostos fundamentais (os axiomas), de modo que o sistema realiza suas operações internas a partir deles. Na lógica interna do sistema normativo, todos os resultados das operações realizadas confirmarão a "verdade" dos axiomas escolhidos. Mesmo que um valor ou interesse social mude na realidade prática, se o valor ou interesse antigo permanecer como o axioma do sistema social, esta estrutura lógica continuará afirmando a "verdade" do valor ou interesse antigo e, ao mesmo tempo, determinando a ilicitude no novo valor ou interesse.

A título de exemplo, podemos ilustrar a afirmação acima por meio da revolução francesa de 1789. A estrutura social e normativa predominante até aquele momento era compreendida a partir de um sistema normativo cujo axioma impunha distinção das pessoas por estamentos, relação de solidariedade entre estamentos, relações de poder baseadas na posse da terra. Mesmo que tal sistema pudesse continuar a ser logicamente operado para identificar o padrão de comportamento social da época, essa forma feudal de sociedade foi esmagada pela

da teoria teorizando sobre si própria, na expectativa de que a realidade social seja descrita a partir do modelo proposto. O sistema tautológico apresentado serve exclusivamente para prever as próprias descrições, num festival de formas eternas e de conteúdos contingentes. A probabilidade de uma determinada sociedade, real e concreta, se parecer com as descrições realizadas pela teoria da autopoiese social só não é baixa porque tal teoria é utilizada como modelo a ser seguido.

Isto parece ficar claro quando LUHMANN afirma que o direito é um sistema que visa à generalização congruente de expectativas normativas (1983:57 e 115), ou seja, é um sistema operativamente fechado que confere, pelas decisóes institucionalizadas no interior do sistema, identifica todas as condutas sociais como conforme e não-conforme o direito. A existência desse sistema confere aos indivíduos a segurança jurídica de que certas condutas serão consideradas lícitas e que suas expectativas nesse sentido não serão frustradas. Dessa consideração surgem dois problemas. O primeiro, que permite afirmar que as condutas esperadas, por não serem comunicaçôes, mas ações, ocorreriam fora do sistema social e não dentro (pois apenas existem comunicações dentro do sistema, tudo o mais pertence ao meio ambiente); e o segundo, que a relação entre comunicação do sistema e conduta do indivíduo não é uma relação nem analítico-dedutiva nem de causalidade, mas de imputação." AUTOR. Revista, n., 2011, p. 165-166.

${ }^{39}$ Kelsen, Hans. Teoria pura do direito, p. 84. 
imposição de um novo sistema social, baseado nos topoi da dignidade da pessoa humana, do individualismo e da impessoalidade do Estado, com as relações de poder baseadas na indústria e no comércio. $\mathrm{O}$ novo sistema normativo foi estabelecido na vida real a partir de relações sociais de poder (ressalte-se, a revolução foi sangrenta, os partidários do sistema anterior ou se submeteram ou foram mortos, seja em combate, seja pela guilhotina), e foi essa situação prática que determinou a substituição dos axiomas anteriores pelos novos. ${ }^{40}$

\section{$\underline{\text { Sobre sistemas lógicos e sistemas normativos }}$}

Inúmeros autores desenvolveram intensa pesquisa sobre a chamada lógica deôntica, isto é, sobre a possibilidade de aplicação das leis do pensamento, próprias da lógica formal, ao mundo do dever ser. Dentre eles, o mais marcante é Georg Henrik VON WRIGHT. ${ }^{41}$ Não obstante, há muitos outros, em especial Ulrich KLUG, com quem KELSEN empreendeu grandes diálogos sobre a relação entre as normas jurídicas e as regras da lógica. ${ }^{22}$ KLUG, em uma resposta a KELSEN, afirmou categoricamente que

Gostaria em primeiro lugar de sustentar a tese de que as regras da Lógica de fato, devem aplicar-se a ambos, ou seja, tanto ao Direito, isto é, às normas, como à Ciência do Direito, isto é, ao conhecimento de seu objeto. Isso resulta já de que em ambos os campos se trata de sistemas de proposição para os quais se pressupõe, ademais, que dentro de cada sistema, em princípios as afirmações não devem estar em contradição entre si. ... Se porém as proposições se contradizem, só se chegará a uma decisão mediante o emprego das regras da Lógica. ${ }^{43}$

Aqui cabem, de nossa parte, as seguintes considerações:

A primeira delas, que acompanha a posição de $\mathrm{KELSEN}^{44}$ é que se deve diferenciar o mundo do ser do mundo do dever ser. O dever ser é formado pelas normas (em especial, as normas jurídicas), cuja característica essencial é a prescritibilidade (imposição de condutas a partir do princípio da imputação), e ele não se confunde com o mundo do ser, em que é possível descrever a realidade pela verificação das relações de causa e efeito entre os fenômenos. Nesse sentido, há uma diferença essencial entre proposiçôes normativas e normas, de modo que as proposições afirmam algo (as proposições normativas afirmam algo sobre a existência das normas, ou melhor,

\footnotetext{
${ }^{40}$ A burguesia revolucionária já possuía consciência desses interesses e já imaginava uma sociedade organizada segundo tais valores há pelo menos 100 anos, data da publicação do Segundo tratado sobre o governo civil, de John Locke (1689), ou um pouco antes, em 1762, data da publicação Do Contrato Social, de Jean-Jacques Rousseau. Mas somente em 1789 houve efetivamente condições materiais para modificação da realidade social e substituição dos valores fundamentais da sociedade francesa, até então medievais, pelos modernos. Em outras palavras: ainda que os burgueses, durante todo o período do renascimento, tivessem efetivamente buscado incluir certos valores seus como reitores da sociedade de sua época, a nobreza teve força política e econômica para impedir tal intento, conservando a estrutura feudal que lhe interessava.

${ }^{41}$ WRIGHT, Georg Henrik von. Hay una lógica de las normas? Trad. Para o castelhano de Daniel Gonzalez Lagier. Título original "Is there a Logic of Norms?" Revista Doxa - Cuadernos de Filosofia del Derecho, n. 26, 2003, p. 31-52.

${ }^{42}$ Kelsen, Hans. Normas jurídicas e análise lógica: correspondência trocada entre os Srs. Hans Kelsen e Ulrich Klug. Trad. Paulo Bonavides. Rio de Janeiro: Forense, 1984.

${ }^{43}$ Reprodução do item 1 da carta de Ulrich KLUG enviada a Hans Kelsen em 27 de abril de 1959. Cf. KelSEN, Hans. Normas jurídicas e análise lógica, p. 3.

${ }^{44}$ Kelsen, Hans. Teoria Pura do Direito, p. 80-84; KelSEN, Hans. Normas jurídicas e análise lógica, p. 88.
} 
sobre sua prescritibilidade), e as normas não afirmam nada, já que o "resultado" de uma norma não é um efeito natural, mas uma consequência jurídica. ${ }^{45}$

A segunda consideração é que KLUG, lógico insuperável, jamais diria que as regras da lógica determinam que resultados podem ser decididos. Ele sabe que, no sistema lógico, as regras da lógica impõem conclusões, decorrentes de operações dedutivas, que não aceitam alternativas ao resultado único e verdadeiro. Ele apenas afirmou que as regras da lógica são úteis para que o aplicador do direito possa exercer a decisão sobre como aplicar a norma ${ }^{46}$ analisando logicamente a verdade ou a falsidade das proposições normativas.

A terceira, e aqui talvez resida o cerne do problema, é que KLUG não distinguia (aliás, como é o caso de VON WRIGHT e KELSEN), de um lado, a estrutura formal do sistema lógico, formado a partir de axiomas matemáticos ou quase-matemáticos e, de outro lado, os sistemas científico e normativo, que se aproveitam da estrutura do sistema lógico para organização de seus objetos de estudo. Tanto o sistema científico quanto o normativo, entendidos como estruturas de pensamento, são construídos a partir de certos axiomas dados como verdadeiros para descrever a realidade (sistema científico-normativo) ou para prescrever a realidade social (sistema normativo). Quando isso ocorre, o princípio da causalidade e o princípio da imputação são transcritos na estrutura lógico-formal de antecedente e consequente.

No caso dos sistemas científicos, como o efeito é resultado necessário da causa eficiente, a transcrição da relação de causa e efeito para uma relação de antecedente e consequente, em que este é resultado deduzido daquele, não provoca problemas sérios, já que os resultados obtidos são basicamente os mesmos. No entanto, no caso de sistemas normativos, a transcrição da relação de causa e consequência (imputação) para uma relação de antecedente e consequente se apresenta problemática, já que a consequência não é um resultado necessário, como se dá na dedução lógico-formal, mas tão-somente esperado. A relação de imputação também não pode ser considerada verdadeira, mas tão-somente válida.

\section{$\underline{\text { Sistemas lógicos são a forma dos sistemas normativos }}$}

Em termos realistas, não importa muito a sistematização lógica utilizada para organizar o sistema

\footnotetext{
${ }^{45}$ À guisa de exemplo: a conduta "matar alguém” é a causa que, no mundo do ser, tem como efeito o fato inescapável de que alguém foi morto e também é a causa que, no mundo do dever ser, impõe que o responsável pelo fato seja processado e julgado para, caso confirmado, seja-lhe imputada a sanção determinada pelo ordenamento jurídico: pena de morte, pena restritiva de liberdade etc. A proposição normativa pela qual se afirma algo sobre "matar alguém" simplesmente declara que essa conduta é considerada típica e que seu autor deve ser processado segundo as regras jurídicas postas pelas autoridades públicas. Se o ordenamento imputa pena de 20 anos para quem realizar tal conduta, a proposição normativa é aquela que afirma ser verdadeira essa realidade jurídica, ou que afirma ser falsa a declaração de que a pena é de morte ou de trabalhos forçados.

${ }^{46}$ Que nos parece ser a mesma conclusão a que chega VON WRIGHT: "Um cálculo como o que elaborei em meu artigo de 1951 é, no melhor dos casos, uma lógica do que chamei 'proposições normativas', isto é, de proposições verdadeiras ou falsas que se referem à existência de tal ou qual norma. Mas uma lógica assim não pode pretender ser uma representação adequada dos sistemas normativos existentes." WRIGHT, Georg Henrik von. Hay una lógica de las normas?, p. 52.
} 
normativo. Em qualquer sociedade, os valores e interesses mais relevantes para o grupo hegemônico ${ }^{47}$ serão postos como os axiomas do sistema interpretativo da conduta humana, de modo a legitimar as condutas condizentes com tais valores e deslegitimar as contrárias. Os grupos sociais dominados até possuem seus próprios axiomas para operar o sistema social, porém não possuem força para substituir os axiomas determinados pelo grupo dominante. Não obstante, em certas circunstâncias, os grupos dominados conseguem impedir que a lógica dedutiva aplicada aos valores dominantes os oprima, mostrando que é possível impedir a realização dos resultados lógicos do sistema normativo. E, se um resultado lógico é impedido, significa que ele não era lógico, mas fruto de uma decisão interessada, baseada em valores e não em verdades. ${ }^{48}$

Talvez quem mais bem tenha explicado isso no âmbito do direito foi Ferdinand LASSALLE, com seus fatores reais de poder. ${ }^{49}$ Mesmo o povo, sem poder econômico ou militar, consegue se organizar quando a opressão é quase insuportável e lutar pela modificação da realidade que lhe oprime. A propósito, a cristalização de certos direitos humanos ou direitos fundamentais cujo conteúdo é contraditório aos valores sociais axiomatizados torna clara a evidência de que a lógica é própria do sistema e não da sociedade.

A lógica, sem dúvida, serve para organizar e dar coerência ao discurso sobre o próprio sistema lógico, à compreensão da realidade material e à compreensão das normas que regem a realidade social. Mas daí a afirmar que os resultados dados pelo sistema lógico são necessários e, portanto, aplicáveis à natureza ou à sociedade, tratase, no mínimo, de um grande equívoco. Cabem, aqui, as palavras de Enrique P. HABA sobre razão e sociedade:

Importa-me deixar bem claro o seguinte. Não nego que seja devido, e até pode ser aconselhável, efetuar reflexões de tipo sistemático para explicar uma realidade pouco racional, ou simplesmente para dar conta dela de forma ordenada. Mas uma coisa é ter ordem (uma ordem baseada na racionalidade ou no sistema) para expor algo; outra, muito distinta, é imaginar-se que, porque se pode pôr ordem em seus próprios pensamentos sobre o que quer que seja, então um objeto real mesmo a que estamos referindo vai proceder, ele também, tão ordenadamente quanto os pensamentos. ${ }^{50}$

\footnotetext{
${ }^{47}$ A cristalização de uma dada compreensão da realidade social decorre da prática reiterada de certas formas de organização social. Em outras palavras, certa visão de mundo acaba se naturalizando na medida em que as pessoas organizam sua produção (sua práxis produtiva, sua vida social) sempre de uma determinada e mesma forma. Aquelas práticas se tornam cada vez mais reais e concretas para o grupo ou classe social, base a partir da qual seus membros traçam e desenvolvem seu modo de compreender a realidade. É justamente esta a posição de Alaôr Caffé ALvES: "Como é possível que a minoria privilegiada domine a maioria despossuída e tire dessa relação as condições de continuidade desse privilégio, mediante a apropriação da mais-valia e a consequente acumulação ampliada dos bens produtivos? Como é possivel fazê-la legítima? A resposta a estas indagações só pode ser encontrada na análise do fenômeno do poder em sua íntima conexão com os processos econômicos e ideológicos emergentes de uma situação estrutural determinada. Como primeira aproximação do problema, é preciso sublinhar que a própria exploração ou a situação de restrição econômica ou a miséria devem ser acolhidas pelos explorados de modo natural, isto é, como não sendo um produto de relações sociais determinadas e a respeito das quais os homens têm ação muito limitada ou não têm qualquer laço de responsabilidade." ALvES, Alaôr Caffé. Estado e Ideologia: aparência e realidade. São Paulo: Brasiliense, 1987, p. 175.

${ }^{48} \mathrm{O}$ sistema lógico conclui num sentido, mas a realidade prática das relações sociais impõe outro resultado. Embora esse resultado seja considerado juridicamente ilícito, em termos sociais é considerado legítimo, situação que pode, mantida a estrutura social, tornar ineficaz a norma que imputa consequências ao ato ilícito.

${ }^{49}$ LASSALLE, Ferdinand. O que é uma constituição?, p. 42 e ss.

${ }^{50}$ HABA, Enrique P. Semiótica ilusionista y semiótica desencantadora: mitomanías de la Razón “constructivista”: racionalidad de los juristas o racionalidad de los iusemióticos? (Por una semiótica realista-crítica del derecho, como alternativa a la idea de "sistema"
} 
Esse autor chama de ilusionismo essa forma de pensamento, pelo qual se imagina possível determinar que a realidade aconteça exatamente na forma ordenada pelas regras internas do sistema lógico. Até faz uma curiosa, porém adequada comparação: se um médico diagnostica a loucura em seu paciente, essa exposição se dá de forma racional, e não louca; "a loucura não deve ser exposta loucamente pelo médico, mas tampouco é questão de crer que olouco deixe de ser louco apenas porque quem fez o diagnóstico foi o médico."51

\section{Nem a sociedade nem o direito são racionais}

A diferença fundamental entre natureza e cultura \sociedade está no fato de esta possuir uma finalidade marcante, algo que não existe na natureza. O homem transforma o mundo natural e, a partir dessa transformação, produz cultura. Toda a produção social é voltada para a consecução de um fim, para a realização de um interesse. Assim, tudo o que se produz visa ao atingimento de uma finalidade, visa a satisfação de um interesse, geralmente fundado numa necessidade-inicialmente metabólica, posteriormente social, mas sempre uma necessidade humana.

Sempre que ações são empreendidas para atingir uma finalidade, a tais ações é atribuído um valor positivo, no sentido de que tais ações são boas, justas, legítimas; de igual modo, a toda ação que impede o atingimento da finalidade, atribui-se um valor negativo, no sentido de que ela é ruim, injusta, ilegítima. As condutas são determinadas conforme esse juízo de valor. No entanto, não há relação de causa e efeito entre a finalidade e as ações, tampouco entre a as ações e a finalidade. O homem possui certa liberdade para decidir quais ações tomar e quais finalidades atingir. ${ }^{52}$

Como, em sociedade, há vários grupos sociais, cada qual com seu interesse singular e finalidades próprias, e como os recursos naturais pelos quais a produção social se realiza são escassos, ${ }^{53}$ acaba por haver conflito sobre quanto e como utilizar os recursos naturais disponíveis. Tais conflitos acabam sendo resolvidos não por acordo ou

jurídico y a la vocación celestial de la Semiótica Jurídica racionalista. Revista Doxa - Cuadernos de Filosofía del Derecho n. 23, 2000, p. 584.

${ }^{51}$ HABA, Enrique P. Semiótica ilusionista..., p. 585.

${ }^{52}$ Quando se afirma a liberdade como uma característica do homem, não se afirma que o homem seria livre das carências e das necessidades impostas pela natureza, mas apenas de ser livre das relações de causalidade. Ele é livre para decidir o que fazer de sua vida no sentido de que suas decisões não são efeitos necessários de uma causa anterior. Essa liberdade de decidir impõe ao homem a responsabilidade pelas escolhas que faz sobre como suprir as carências e satisfazer essas necessidades, e também pelas consequências decorrentes dessas escolhas ( $C f$, entre outros, KeLSEN, Hans. Teoria pura do direito, p. 102-1 10). Porém, ao se levar essa consideração individualista para o campo da sociedade, as decisões hegemônicas sobre como satisfazer os interesses são postas como se cada indivíduo tivesse decidido daquela forma, imputando-se a cada um deles a responsabilidade pelo cumprimento dessa forma de organização social.

${ }^{53}$ Esse pressuposto não é fictício, mas fundado na realidade material e também na teoria econômica. Não há recursos naturais suficientes para que todas as necessidades humanas sejam satisfeitas ao mesmo tempo e de modo completo, fenômeno que se define pelo conceito de escassez. As decisões políticas sobre as formas de utilização dos recursos escassos é objeto das mais variadas ciências sociais, da economia e do direito à sociologia. 
por contrato social, mas por luta: ${ }^{54}$ cada grupo social pretende a utilização desses recursos para atingir e satisfazer, primeiro, os próprios interesses. Essa luta possui uma dimensão política muito clara, já que política é justamente o campo social em que se dão as decisões sobre o destino dos recursos sociais.

Algo que precisa ficar claro é que as decisões políticas não se dão de forma respeitadora e isenta, no âmbito de um afável debate em que os envolvidos acatam racionalmente o que foi decidido, mesmo que contrariando seus interesses. Há luta ferrenha tanto antes da tomada das decisões (para se decidir) quanto após (para se executar o que foi decidido). Todas as forças sociais se envolvem para definir o que fazer com os recursos sociais e, no embate de forças, o grupo com mais poder detém vantagem evidente. Esse grupo hegemônico, que por sua força é capaz de impor seus interesses em maior medida que os demais grupos, tende a se utilizar de recursos ideológicos para justificar ou consolidar sua posição: noções de bem comum, de vontade geral, de interesse coletivo são topoi úteis para cristalizar as relações sociais segundo a correlação de forças e, ato contínuo, positivar tais relações na forma de norma jurídica.

Ao se estabelecer um sistema normativo para determinar esse estado de coisas, a lógica interna desse sistema passa a operar segundo os valores e interesses que foram axiomatizados como princípios fundamentais do sistema social: passa-se a entender tais princípios como impessoais e comuns ao interesse de todos os membros da sociedade, buscando com isso thes atribuir legitimidade para que sejam seguidos. Não obstante, tais princípios servem apenas para reproduzir a situação de desigualdade social estabelecida no encontro de forças políticas. ${ }^{55}$

Importa deixar claro que é perfeitamente possível descrever essa situação social e essa normatização jurídica de forma racional. Essa é a função das ciências sociais e da ciência do direito. Isso não significa, porém, que a sociedade e o direito se tornem racionais apenas porque foram racionalmente descritos. Sobre o direito, o próprio KELSEN deixou claro que ele não continha qualquer pureza (racionalidade): pura era apenas a sua teoria. ${ }^{56}$

Tercio Sampaio FERRAZ JUNIOR é claro ao afirmar que há uma diferença essencial entre a ciência e o direito. Naquela, busca-se a resposta para um "eu sei", enquanto neste busca-se uma resposta para um "eu quero". ${ }^{57}$ A ciência busca a verdade, enquanto pelo direito se busca a satisfação de interesses por meio de um ato de vontade

\footnotetext{
${ }^{54}$ No âmbito da ciência do direito, ao menos desde 1872 se reconhece que o direito não se dá senão por meio de luta, e que tal luta se dá por causa dos interesses conflitantes. Cf. a célebre palestra de IHERING, Rudolf von. A luta pelo direito. Trad. Edson Bini. Bauru: Edipro, 2001, p. 25.

${ }^{55}$ Ressalte-se, assim, que nesse sentido tem razão LUHMANN quando afirma que o sistema jurídico não faz justiça, e que justiça não é sequer parte do sistema (LuHMANn, Niklas. El derecho de la sociedad. Trad. para o castelhano de Javier Torres Nafarrate. México: Herder, 2005, p. 275-298). A única função do sistema é reproduzir os valores e interesses do grupo hegemônico (em detrimento de valores e interesses de outros grupos sociais). O sistema, ao se reproduzir, realiza as mesmas e iguais operações e prescreve as mesmas e iguais condições a todas as pessoas. Porém, as pessoas não são iguais para que seja justo receberem o mesmo tratamento. Elas são ficticiamente consideradas iguais entre si apenas para dar-se a impressão de que o sistema opera com justiça.

${ }^{56}$ KeLSEN, Hans. Teoria pura do direito, p. 1.
} 
(eis aqui um problema sério: como conciliar as descrições categóricas da ciência e os anseios particulares da sociedade?). O que talvez precisasse ficar mais claro é que a ciência do direito até descreve a realidade social e normativa, mas o faz somente a partir de um ato de vontade, um ato político altamente interessado, que lhe confere um estatuto deontológico. Os princípios, os pontos de partida da teoria do direito, direcionam o entendimento muito mais para a preservação de certos interesses e elevação de certos valores do que para uma objetiva constatação da realidade jurídica.

\section{A construção de um lugar-comum}

A partir de tais interesses e necessidades, apresenta-se um modelo de organização de sociedade. A justificação das ações cuja finalidade é suprir esses interesses e necessidades assume a forma de princípios argumentativos que, muito embora sejam apresentados como descritivos de uma organização social, são essencialmente um modelo prescritivo de sociedade, já que tais princípios, construídos muito mais a partir do interesse do observador que do objeto observado, não dizem como a sociedade é, mas como ela deve ser. ${ }^{58}$ Ato contínuo, a organização dessa sociedade é positivada na forma de normas, cristalizando-se em termos jurídicos a estrutura definida politicamente.

Toda norma jurídica, por ser o sentido objetivo da vontade de uma autoridade pública, ${ }^{59}$ deve ser compreendida no âmbito do motivo de sua positivação e também da finalidade de sua positivação. ${ }^{60}$ Isso só é possível a partir da compreensão da realidade social que, de alguma forma, determinou sua criação e também sua aplicação. Em outras palavras, a compreensão do sentido das normas jurídicas só é possível se os princípios argumentativos forem levados em consideração. Esses lugares-comuns, úteis à organização social, são igualmente úteis à teoria do direito para compreensão das normas jurídicas, e no âmbito da teoria jurídica são amplamente conhecidos como princípios gerais do direito, cânones interpretativos que dão racionalidade à relação entre a

\footnotetext{
${ }^{57}$ Cf. Ferraz JR., Tercio Sampaio. Introdução ao estudo do direito: técnica, decisão, dominação. 4 ed. São Paulo: Atlas, 2003, p. 262.

${ }^{58}$ Segundo KELSEN, as proposições normativas afirmam o que o direito é e não como ele deve ser. Isso é correto. Contudo, se ampliarmos o campo de visão, veremos que a proposição normativa não é afirmada por um observador neutro, que compreende a norma a partir de princípios argumentativos de caráter altamente prescritivo, pois baseados em valores e não em verdades. Daí porque, neste trabalho, identificamos as proposições normativas com topoiargumentativos.

${ }^{59}$ Essa é a irrepreensível definição de norma para KELSEN (que, a nosso ver, seria mais adequada à compreensão de texto normativo que de norma). Cf. Kelsen, Hans. Teoria pura do direito, p. 8.

${ }^{60}$ Todo agente público tem o dever de expressar o motivo (para alguns, causa) dos atos realizados no exercício de suas funções, bem como explicar sua finalidade, para fins de controle. $C f$, a este respeito, o artigo $2^{\circ}$ da Lei da Ação Popular, Lei Federal n. 4717/1965 ou, sobre essa "infraestrutura" dos atos públicos, especificamente sobre motivo e finalidade, cf.CARVALHO FILHO, José dos Santos. Manual de direito administrativo. 25 ed. São Paulo: Atlas, 2012, p. 111-119. No âmbito da Teoria do Direito, quem se expressou nesse sentido foi Alf Ross: "A compreensão da lei por parte do juiz dependerá sempre de sua compreensão dos motivos e propósitos da lei. O que distingue um estilo subjetivo de um estilo objetivo de interpretação é, realmente, apenas que de acordo com o primeiro, e não de acordo com o segundo, a história legislativa é admitida como evidência para expor o propósito da lei e projetar luz sobre as minúcias de seu significado." Ross, Alf. Direito e Justiça. Trad. Edson Bini. Bauru: Edipro, 2000, \$28, p. 172.
} 
forma jurídica e o seu conteúdo, em que estão presentes os interesses e valores sociais mais relevantes.

Muitas vezes, o cientista do direito se apresenta neutro ao descrever tais princípios argumentativos como o fundamento da norma jurídica. Ao fazer isso, acaba simplesmente reproduzindo o valor contido no princípio que utilizou para interpretar a norma. Mais adequado, inclusive em termos científicos, seria identificar o valor e o interesse que subjazem ao princípio, dentre outras formas pela constatação da existência dos motivos e das finalidades inerentes à aplicação da norma interpretada. Aí, sim, o teórico faria rigorosa análise do objeto de estudo.

Conforme afirmado ao longo deste trabalho, qualquer princípio identificado pelo teórico no âmbito da ciência do direito é um topos argumentativo. Caso esse topos tenha sido alçado a axioma do sistema normativo, toda a estrutura lógica do sistema passa a declarar a "verdade" de seu enunciado, o que lhe dá ainda mais força argumentativa. Por outro lado, se aquele princípio tiver conteúdo contraditório ao enunciado do axioma, o sistema simplesmente nega validade a ele. Nesse sentido, os princípios aos que se confere a característica de "mandamentos nucleares do sistema" são justamente esses topoi axiomatizados, posto que eles estruturam o entendimento de todo o sistema jurídico, que dão sentido às normas do ordenamento. Por isso que Bandeira de MELLO afirmou que contrariar esse tipo de princípio seria pior que contrariar uma norma jurídica. ${ }^{61}$

Princípios não-axiomatizados também são importantes, mas se referem a valores e interesses sociais que não foram, por questões de conflito social, elevados a princípios fundamentais do sistema lógico normativo. Eles não são identificados como válidos pelo sistema lógico, pois seus enunciados são contrários aos realizados por suas operações lógico-dedutivas. Daí a necessidade de os grupos sociais, interessados em dar importância a outros princípios, desafiarem as bases do sistema normativo a partir de novas construções. De todo modo, qualquer teórico interessado em conferir força interpretativa a um princípio sabe que, embora esse topos possua inegável consistência hermenêutica, ele não é uma norma jurídica, que pode ser interpretada de inúmeras outras formas, e que em regra é interpretada e aplicada conforme os princípios axiomatizados no sistema normativo.

\footnotetext{
${ }^{61}$ Cf. Mello, Celso Antonio Bandeira de. Elementos de direito administrativo. São Paulo: Revista dos Tribunais, 1980, p. 230. A expressão "mandamento nuclear do sistema" também é dele. Ressalte-se aqui que Bandeira de Mello já tratava os axiomas do sistema normativo, próprios da ciência do direito e não do direito, como elementos prescritivos e não descritivos, deixando claro que os princípios gerais do direito, pelo direcionamento que davam à compreensão de todas as normas jurídicas, embora não fossem normas, também prescreviam condutas, já que era por esse conteúdo normativo que as normas jurídicas propriamente ditas tinham seu entendimento construído para consequente aplicação. Eis porque entendemos, a partir de uma perspectiva realista, que norma não deve se confundir com o texto normativo (por exemplo, a lei escrita): a norma é o resultado da interpretação e da aplicação do texto à realidade normada, interpretação esta que é integralmente direcionada pelos princípios. Num sentido muito próximo a este, cf. Ávila, Humberto. Teoria dos princípios: da definição à aplicação dos príncípios jurídicos. 4 ed. São Paulo: Malheiros, 2004, p. 22-23.
} 


\section{CONCLUSÕES FINAIS: QUANDO O PRINCIPIO DEIXA DE SER UM ARGUMENTO PARA SE TORNAR UMA NORMA}

Conforme o campo de estudo, o princípio pode ter a natureza de um axioma (lógica), de uma hipótese explicativa causal (ciências da natureza), de um lugar comum (ciências sociais, em especial o direito). Deixemos de lado os princípios causais, próprios dos sistemas científicos, para tratar dos princípios como axioma e como lugares-comuns (topoi).

Não existe uma organização verdadeira. O critério de organização de um conjunto de elementos pode variar conforme o interesse e a praticidade, ou a necessidade da organização. Os homens vivem em sociedade há pelo menos 40 séculos e, em cada tempo e lugar, os grupamentos sociais tiveram as mais diferentes formas, simplesmente porque o critério de organização não é um dado a priori nem decorre da experiência que se tem do objeto organizado, mas uma escolha do organizador. O que pode ser afirmado é que, em cada tempo e lugar, sempre houve racionalidade entre a organização e o conteúdo suportado por ela pois, do contrário, ocorreria desagregação social. Em outras palavras, sempre foi possível justificar o critério adotado a partir de um interesse ou uma necessidade. ${ }^{62}$

A quantidade de princípios argumentativos que se apresentam na doutrina nos dias de hoje talvez seja tão grande quanto a pluralidade de interesses sociais que surgem dos mais variados grupos sociais. Todo interesse social possui legitimidade para ser apresentado como relevante, e ele invariavelmente é apresentado na forma de um princípio, um lugar-comum pelo qual se apresenta o interesse ou necessidade como um valor social e que aponta para as ações práticas necessárias ao atingimento do fim identificado pelo princípio.

$\mathrm{Na}$ prática, sempre pode haver conflito entre os interesses sociais divergentes, conflito esse que se reproduz na colisão entre os respectivos princípios justificadores de cada um dos interesses. Trata-se de disputa ideológica decorrente de distintas (e até contraditórias) visões de mundo. Visões distintas decorrem do fato de a sociedade possuir vários grupos sociais, cada qual interessado no uso dos recursos sociais escassos para atingir a sua finalidade. Os valores e interesses de cada grupo são o fundamento que legitima seus pontos de vista e a busca pelas finalidades que mais bem concretizem seus valores e interesses.

Porém, quando certos valores e interesses são positivados na forma de normas jurídicas, pontos de vista

\footnotetext{
${ }^{62}$ Em sociedades primitivas, em que a divisão social do trabalho é relativamente pequena, o interesse da sociedade pode se confundir com o interesse de cada membro da sociedade, já que todos os integrantes participam da produção e da distribuição dos bens sociais em medida equivalente. No entanto, na medida em que as sociedades se tornam mais complexas e a divisão social do trabalho se intensifica, surgem no seio da sociedade grupos que se distinguem justamente pela forma como cada grupo participa da produção e da distribuição dos bens sociais. Passa a existir diferença marcante entre o interesse social e o interesse individual. Esses grupos, conforme sua força e capacidade de mobilização, intentam organizar a sociedade para promoção de seus valores e interesses, ao menos em maior medida que para promoção dos demais valores e interesses sociais. Tais valores e interesses são
} 
divergentes se tornam ilícitos. Esse é o resultado da aplicação da definição teórica de Robert ALEXY, ${ }^{63}$ para quem o termo princípio não se refere apenas à teoria, não se refere apenas à interpretação. Ao afirmar a existência de princípios positivados como espécies de normas jurídicas, ALEXY impõe que esses princípios-normas sejam sempre levados em consideração, já que ao intérprete se permite não levar argumentos divergentes em conta, e até mesmo contrariar a lógica de um sistema normativo, mas não the é admitido usar de argumentos que se mostrem contra legem.

\title{
ON THE THEORETICAL DISTINCTION BETWEEN LOGICAL, SCIENTIFIC AND LEGAL PRINCIPLES
}

\begin{abstract}
In realistic terms, Law is understood as a consequence of social relations and not as a natural effect or a logical deduction that arises from those same relations. The theory of Law shall not be developed under the same standards either of natural science or formal logic. The principles of nature and logic, which respectively furnish the basis for nature sciences and logic, are essentially distinct from the normative principles, that give grounds to the theory of Law. The confusion among them leads to understand Law as if it could be stated in the form of a system based on principles of nature, to make it appears as if it was true, or on logical principles, to make it appears as if it was immutable.
\end{abstract}

Keywords: Law and Theory of Law. Legal logic. Logical, scientific and normative principles. Social systems as normative systems.

\section{REFERÊNCIA DAS FONTES CITADAS}

ALEXY, Robert. Teoría de los derechos fundamentales. Trad. para o castelhano de Ernesto Garzón Valdés. Madri: CEPC, 2001.

ALVES, Alaôr Caffé. Lógica: Pensamento formal e argumentação: Elementos para o discurso jurídico. 3 ed. São Paulo: Quartier Latin, 2003.

ALVES, Paula e VAZ, Catarina. O número imaginário existe realmente? Disponível em http://www.educ.fc.ul.pt/docentes/opombo/seminario/euler/iexiste.htm. Acesso em 6.set.2012.

ÁVILA, Humberto. Teoria dos princípios: da definição à aplicação dos princípios jurídicos. 4 ed. São Paulo: Malheiros, 2004.

apresentados como valores e interesses comuns, como argumentos de um estado de coisas que beneficiaria a sociedade como um todo.

${ }^{63}$ ALEXY, Robert. Teoría de los derechos fundamentales. Trad. para o castelhano de Ernesto Garzón Valdés. Madri: CEPC, 2001. 
Repensando o princípio da supremacia do interesse público sobre o particular. Revista Diálogo Jurídico. Ano I. vol. I. n. 7, out/2001, p. 1-30. Disponível no URL: http://www.direitodoestado.com.br/rere.asp. Acesso em 10 de setembro de 2012;

CANARIS, Claus-Wilhelm. Pensamento sistemático e conceito de sistema na ciência do direito. Trad. A. Menezes Cordeiro. 2 ed. Lisboa: Calouste Gulbenkian, 1996;

CAPELLA, Juan-Ramon. El derecho como lenguaje: un análisis lógico. Barcelona: Ariel, 1968;

CARVALHO FILHO, José dos Santos. Manual de direito administrativo. 25 ed. São Paulo: Atlas, 2012;

CASSIRER, Ernst. Antropologia filosófica: Ensaio sobre o homem. Trad. Vicente Felix de Queiroz. 2 ed. São Paulo: Mestre Jou, 1977;

COPI, Irving M. Introdução à lógica. Trad. Álvaro Cabral. 2 ed. São Paulo: Mestre Jou, 1978;

FERRAZ JR., Tercio Sampaio. Introdução ao estudo do direito: técnica, decisão, dominação. 4 ed. São Paulo: Atlas, 2003;

HABA, Enrique P. Metodología realista-crítica y ética del razonamiento judicial: Realismo jurídico como alternativa práctica al discurso de los jueces. Revista Doxa - Cuadernos de Filosofía del Derecho n. 25, 2002, p 503-531;

Semiótica ilusionista y semiótica desencantadora: Mitomanías de la razón "constructivista": racionalidad de los juristas o racionalidad de los iusemióticos? (Por una semiótica realista-crítica del derecho, como alternativa a la idea de "sistema" jurídico y a la vocación celestial de la Semiótica Jurídica racionalista. Revista Doxa Cuadernos de Filosofía del Derecho n. 23, 2000, p. 561-596;

HUME, David. Investigação acerca do entendimento humano. Coleção Os Pensadores Trad. Anoar Aiex. São Paulo: Nova Cultural, 1996;

IHERING, Rudolf Von. A Luta pelo direito. Trad. Edson Bini. Bauru: Edipro, 2001;

KANT, Immanuel. Crítica da razão pura. Trad. Manuela Pinto dos Santos e Alexandre Fradique Morujão. Baseada na edição crítica de Raymund Schmidt, confrontada com a edição da Academia de Berlim e com a edição de Ernst Cassirer. 5 ed. Lisboa: Calouste Gulbenkian, 2001;

Manual dos cursos de lógica geral. Trad. Fausto Castilho. 2 ed. Campinas: Editora da Unicamp, 2003.

KELSEN, Hans. Normas jurídicas e análise lógica: correspondência trocada entre os Srs. Hans KELSEN e Ulrich Klug. Trad. Paulo Bonavides. Rio de Janeiro: Forense, 1984.

Teoria pura do direito. Trad. João Baptista Machado. 6 ed. São Paulo: Martins Fontes, 2003.

LASSALLE, Ferdinand. O que é uma Constituição? Trad. Hiltomar Martins Oliveira. Belo Horizonte: Líder, 2001;

LUHMANN, Niklas. El derecho de la sociedad. Trad. para o castelhano de Javier Torres Nafarrate. 2 ed. México: Editorial Herder, 2005;

Social systems. Trad. para o inglês de John Bednarz. Stanford: Stanford University Press, 1995 (versão para a língua inglesa de Soziale systeme. Grundrisseiner allgemeinem theorie); 
MASTRODI, Josué. Levando o conceito de autopoiese a sério: por que o direito não pode ser compreendido a partir do paradigma de Niklas LUHMANN. Revista da Faculdade de Direito Candido Mendes, v. 16, p. 155-173, 2011; 2012 ;

Sobre o Real Fundamento dos Direitos Fundamentais. Revista Digital de Direito Público, v. 1, p. 150-187,

MELLO, Celso Antonio Bandeira de. Elementos de direito administrativo. São Paulo: Revista dos Tribunais, 1980;

NIETZSCHE, Friedrich. A filosofia na época trágica dos gregos ( $\$ \$$ 9, 10, 11, 12 e 13). In Os Pré-Socráticos: Vida e Obra. Coleção Os Pensadores. Trad. José Cavalcanti de Souza et al. São Paulo: Nova Cultural, 1996, p. 127-138;

PARMÊNIDES DE ELEIA. “Fragmentos.” In Os Pré-Socráticos: Vida e Obra. Coleção Os Pensadores. Trad. José Cavalcanti de Souza et al. São Paulo: Nova Cultural, 1996, p. 121-127;

ROSS, Alf. Direito e Justiça. Trad. Edson Bini. Bauru: Edipro, 2000;

VAIHINGER, Hans. The Philosophy of 'as if. Trad. para o inglês de C. K. Ogden. Londres: Routledge, 1952;

WITTGENSTEIN, Ludwig. Investigações filosóficas. Coleção Os Pensadores. Trad. José Carlos Bruni. São Paulo: Abril Cultural, 2000;

WRIGHT, Georg Henrik von. Hay una lógica de las normas? Trad. para o castelhano de Daniel González Lagier. Revista Doxa - Cuadernos de Filosofía del Derecho n 26, 2003, p. 31-52.

Trabalho enviado em 22 de agosto de 2016.

Aceito em 05 de fevereiro de 2017. 